\title{
Head shape determination and cranial evaluation using anatomical landmarks in children with sickle cell disease (SCD)
}

\author{
M.A. Musa', A.D. Zagga', K. Musa², M. Danfulani' ${ }^{3}$, H. Ahmed ${ }^{4}$ \\ ${ }^{1}$ Department of Anatomy, College of Health Sciences, Usmanu Danfodiyo University, Sokoto, Nigeria, ${ }^{2}$ Dental Unit, Sir Yahya Memorial \\ Hospital, Birnin Kebbi, Nigeria, ${ }^{3}$ Department of Radiology, Usmanu Danfodiyo University Teaching Hospital, Sokoto, Nigeria, ${ }^{4}$ Department of \\ Pediatrics, College of Health Sciences, Usmanu Danfodiyo University Teaching Hospital, Sokoto, Nigeria
}

\section{A B S TR A C T}

Background: Sickle cell disease is one of the commonest diseases widespread in sub-Saharan Africa and Nigeria in particular. This study investigated the possible effects of sickle cell disease (SCD) on the cranial index and pattern of head shapes of children with sickle cell disease in comparison with that of children without SCD. Methods: The head length, head width of 103 children (54 males and 49 females) with sickle cell disease and 218 normal growing non-sickle cell disease children (121 males and 97 females) aged 0-18 years old were measured and their cranial indices calculated. Results: The mean $\mathrm{Cl}$ for normal growing non sickle cell disease children was $79.82 \pm 3.35$ and that of the sickle cell disease children was $80.12 \pm 3.39$ which was not statistically significant $(p=0.4526)$. However, the difference between the mean $\mathrm{Cl}$ of males in both groups was not significant $(p=0.9535)$ likewise in females $(p=0.3127)$. The mean head circumference in sickle cell disease children was $48.89 \pm 3.15$ as against that of the normal growing non-sickle cell disease children $44.97 \pm 6.07$ and this difference was also not statistically significant ( $p=>0.05)$. Conclusion: The head shapes as per the present study could be classified as mesocephalic in normal growing non-sickle cell disease children and brachycephalic in sickle cell disease children. Thus, it has been deduced that sickle cell disease could probably have an effect on head length, head width, cranial index and head circumference of affected children.

Key words: Cranial Index, Head circumference, Head shape, Sickle cell disease, Children
Access this article online Website:

http://nepjol.info/index.php/AJMS

\section{INTRODUCTION}

Biologic variation allows the unique craniofacial character and the many asymmetries found in each individual. ${ }^{1}$ Sickle cell anemia is common in Nigeria with prevalence values ranging from $2 \%$ to $3 \%$ of the population. ${ }^{2,3}$

Sickle cell disease (SCD) is one of the commonest single gene disorders in man and has a widespread distribution in different parts of the world with variable clinical manifestations. ${ }^{4}$ Several studies conducted on sickle cell disease have shown that sickle cell disease affects the growth and development of children. ${ }^{5}$ Findings have shown that American-Black children with sickle cell disease were shorter with lower body weights than normal growing children. ${ }^{6}$ Subjects with Sickle cell disease have been reported to present various growth deficits such as malocclusion and stunting compared to unaffected peers.

The characteristics physical and morphological (craniometric and morphometric) body features of long standing sickle cell disease has been documented to include bossing of the skull, hyperplasis of the maxilla, general underweight, linear stature with comparatively narrow shoulder and hips, disproportionately long and spindly extremities compared to the trunk. ${ }^{8}$

The importance of conducting craniometric or cephalometric studies cannot be over emphasized especially in the areas of pediatrics, plastic surgery, oral surgery and 
forensic medicine. ${ }^{9,10}$ Cranial Index (C.I) is one of the clinically recognized anthropometric parameter in the investigation of craniofacial skeleton because of its validity and practicability. ${ }^{11}$

Cranial index is the most investigated craniofacial parameter as it utilizes the length and breadth of the head which are very helpful in the study of secular trends. ${ }^{12,13,14}$ Cranial Index is used in determining the variations in shape of the head and face in newborns ${ }^{15}$ and in determining head dimensions in fetuses. ${ }^{16}$

However, due to paucity of data on the physical or morphometric cranial indices of sickle cell children in Nigeria, ${ }^{17}$ this study provides standardized craniometric measurements for children with SCD that will serve as baseline reference measurements for growth monitoring and evaluation.

\section{MATERIALS AND METHODS}

\section{Study location}

This study was conducted in the Institute of Child Health Unit of the Usmanu Danfodiyo University Teaching Hospital (UDUTH), Sokoto, Nigeria.

\section{Measurements and procedures}

The head measurements were carried out in the Pediatric Sickle Cell Anemia Clinic UDUTH. Craniometric measurements were taken from 321 children of pediatric age group 0-18 years old that visited the clinic during the period of the study. The subjects were made up of 103 children who had been diagnosed with sickle cell anemia and who attended the Sickle cell clinic. 218 normal growing non-sickle cell disease children on routine check up at the center were also recruited in this study. Children with craniofacial malformations or a history or signs of craniofacial syndromes were excluded from this study.

The bio-data of the subjects were obtained and this includes their names, hospital card numbers, sex and age. Measurements were taken using standard recognized anatomical landmarks. Internationally accepted anthropometric instruments were used to ensure great accuracy and reproducibility. All measurements were taken to the nearest $0.1 \mathrm{~cm} .{ }^{18}$

\section{The cranial index}

The cranial index (CI) was calculated using cranial measurements obtained from each subject. The Head Length (Greatest antero-posterior diameter) and head width (maximum transverse diameter between two fixed points) were measured with the help of a spreading caliper. ${ }^{18,19}$ The head length was measured from glabella to opistocranium while the head breadth was measured as the distance between euryons. ${ }^{19}$ The Spreading caliper with rounded ends the tips are made to touch the cranial points and the reading is observed on the scale. ${ }^{18,19}$

The cranial index is calculated as the ratio of head width to head length multiplied by 100 . The cranial index has been used to classify head shapes into four international categories namely dolicocephalic $(\mathrm{CI}=<74.9)$, mesocephalic $(\mathrm{CI}=75-79.9)$ brachycephalic $(\mathrm{CI}=80-84.9)$ and hyperbrachycephalic $(\mathrm{CI}=>85)$. ${ }^{9,} 20$

\section{The head circumference}

The protocol for head circumference measurement used in this study is part of an examination survey on infants and children conducted by The National Health and Nutrition Examination Survey. ${ }^{21}$

The Head circumference of the children was measured using a flexible non-stretchable measuring tape. ${ }^{21,22}$ The head circumference measuring tape was placed around the child's head so that the tape lies: across the frontal bones of the skull; slightly above the eyebrows; perpendicular to the long axis of the face; above the ears; and over the occipital prominence at the back of the head. The tape was moved up and down over the back of the head to locate the maximal circumference. ${ }^{23}$

The "zero mark" on the measuring tape was placed on the side of the forehead above the top of the infant's ears and slightly above the supraorbital ridges - the eyebrows. ${ }^{21}$ The parents of some of the infants also assisted in holding the tape or comforting the child during the measurement. It was ensured that the tape was firm against the head, and meets the start of the tape on the forehead. ${ }^{21}$ The tape was snugly pulled to compress the hair and underlying soft tissues. The head circumference was read to the nearest $0.1 \mathrm{~cm}$. The head circumference of each child was re-measured a second time and the average of the two measures in closest agreement was recorded. ${ }^{21}$

\section{Ethical consideration}

Ethical clearance was obtained from relevant Institutions and Departments for this study. Ethical consideration included taking informed consent from parents and guardians of study participants, using Hospital card numbers to maintain confidentiality and making recommendations to appropriate authorities.

\section{Statistical analysis}

The data obtained from the measurements of head length, head width were used in determining the cranial index. The cranial index and while the head circumference values were entered and analyzed using the Statistical Package for 
Social Sciences (SPSS) version 17 for Windows. Descriptive Statistics presented in Tables 1, 2, 3, 4 and 5. Student-t-Test was used for comparison between means and statistical significance set at $\mathrm{p}=<0.05$.

\section{RESULTS}

Tables 1 and 2 presents the mean \pm SD values of cranial indices of children with SCD and those without SCD. All measurements were age-related. However, the children with SCD had a higher cranial index (mean CI=80.12 \pm 3.39 ) than those of without SCD (mean $\mathrm{CI}=79.82 \pm 3.35$ ). Thus,

\begin{tabular}{|c|c|c|c|c|c|}
\hline \multirow[t]{2}{*}{$\begin{array}{l}\text { Age group } \\
\text { (years) }\end{array}$} & \multicolumn{2}{|c|}{$\begin{array}{l}\text { Males with } \\
\text { SCD }\end{array}$} & \multicolumn{2}{|c|}{$\begin{array}{l}\text { Males without } \\
\text { SCD }\end{array}$} & \multirow[t]{2}{*}{$p$ value } \\
\hline & $\mathbf{N}$ & Mean $\pm S D$ & $\mathbf{N}$ & Mean士SD & \\
\hline $0-3$ & 19 & $78.55 \pm 3.04$ & 66 & $79.17 \pm 2.91$ & 0.4338 \\
\hline $4-7$ & 16 & $78.74 \pm 3.74$ & 17 & $78.43 \pm 3.33$ & 0.8039 \\
\hline $8-11$ & 12 & $79.13 \pm 2.69$ & 21 & $79.04 \pm 3.11$ & 0.9289 \\
\hline $12-15$ & 7 & $81.64 \pm 3.27$ & 17 & $80.05 \pm 4.21$ & 0.3368 \\
\hline $16-18$ & - & - & - & - & - \\
\hline
\end{tabular}

$\mathrm{N}=$ Sample size; *Statistically significant difference; SD=Standard deviation

\begin{tabular}{|c|c|c|c|c|c|}
\hline \multirow[t]{2}{*}{$\begin{array}{l}\text { Age group } \\
\text { (years) }\end{array}$} & \multicolumn{2}{|c|}{$\begin{array}{l}\text { Females } \\
\text { with SCD }\end{array}$} & \multicolumn{2}{|c|}{$\begin{array}{c}\text { Females } \\
\text { without SCD }\end{array}$} & \multirow[t]{2}{*}{$p$ value } \\
\hline & $\mathbf{N}$ & Mean $\pm S D$ & $\mathbf{N}$ & Mean $\pm S D$ & \\
\hline $0-3$ & 22 & $81.48 \pm 2.87$ & 75 & $80.86 \pm 3.31$ & 0.3965 \\
\hline $4-7$ & 12 & $80.12 \pm 2.88$ & 14 & $80.17 \pm 3.84$ & 0.4831 \\
\hline 8-11 & 10 & $79.92 \pm 3.94$ & 3 & $80.08 \pm 0.52$ & 0.9017 \\
\hline $12-15$ & 4 & $83.47 \pm 3.82$ & 5 & $78.72 \pm 3.73$ & 0.1067 \\
\hline $16-18$ & 1 & $80.36 \pm 0.00$ & 0 & 0 & $<0.05^{*}$ \\
\hline
\end{tabular}

\begin{tabular}{|c|c|c|c|c|c|}
\hline \multirow[t]{2}{*}{$\begin{array}{l}\text { Age group } \\
\text { (years) }\end{array}$} & \multicolumn{2}{|c|}{$\begin{array}{l}\text { Males with } \\
\text { SCD }\end{array}$} & \multicolumn{2}{|c|}{$\begin{array}{l}\text { Males without } \\
\text { SCD }\end{array}$} & \multirow[t]{2}{*}{$p$ value } \\
\hline & $\mathbf{N}$ & Mean $\pm S D$ & $\mathbf{N}$ & Mean $\pm S D$ & \\
\hline $0-3$ & 19 & $46.11 \pm 4.62$ & 66 & $43.12 \pm 5.61$ & $0.02333^{*}$ \\
\hline $4-7$ & 16 & $50.25 \pm 1.34$ & 17 & $49.29 \pm 1.53$ & 0.06548 \\
\hline $8-11$ & 12 & $50.42 \pm 1.08$ & 21 & $51.05 \pm 2.04$ & 0.2545 \\
\hline $12-15$ & 7 & $50.00 \pm 1.73$ & 17 & $51.24 \pm 1.52$ & 0.1311 \\
\hline $16-18$ & - & - & - & - & - \\
\hline
\end{tabular}

the head shapes as per the present study could be classified as mesocephalic in normal growing children without SCD and brachycephalic in children with SCD.

Moreover, the mean cranial index for the males with SCD was $79.13 \pm 3.29$ as against $79.16 \pm 3.19$ of the normal growing males without SCD while that of the females varies from $81.21 \pm 3.39$ for the sickle cell group to $80.63 \pm 3.36$ in the non-sickle cell group. Statistically, all the age groups in male children with SCD in comparison to the normal growing males without SCD, showed no significant difference $(p>0.05)$ as presented in Table 1. The female children with SCD did not show any statistical significant difference too in comparison to the normal growing females without SCD except for age group 16-18 years where the difference was statistically significant $(\mathrm{p}<0.0001)$ as shown in Table 2.

The mean head circumference (HC) value for the males with SCD was $48.79 \pm 3.51$ as against $46.49 \pm 5.71$ of the normal growing males without SCD and this was statistically significant $(\mathrm{p}=0.0013)$ while that of the females varies from $49.00 \pm 2.72$ for the sickle cell group to $43.06 \pm 5.99$ in the females without SCD and was not significant $(p=>0.05)$.

Statistically, the HC of all the age groups in male children with SCD in comparison to the normal growing children without SCD, showed no significant difference $(\mathrm{p}>0.05)$ except for age group 0-3 years which was statistically significant $(p=0.0233)$ as presented in Table 3 . The female children with SCD did not show any statistical significant difference too in comparison to the normal growing females without SCD except for age group 16-18 years where the difference was statistically significant $(\mathrm{p}<0.05)$ as shown in Table 4.

Furthermore the differences in cranial index between the sexes of children with SCD and normal growing children without SCD were statistically significant with $\mathrm{p}$ values of 0.002 and 0.003 respectively. However the differences

\begin{tabular}{|c|c|c|c|c|c|}
\hline \multirow[t]{2}{*}{$\begin{array}{l}\text { Age group } \\
\text { (years) }\end{array}$} & \multicolumn{2}{|c|}{$\begin{array}{l}\text { Females } \\
\text { with SCD }\end{array}$} & \multicolumn{2}{|c|}{$\begin{array}{c}\text { Females } \\
\text { without SCD }\end{array}$} & \multirow[t]{2}{*}{$p$ value } \\
\hline & $\mathbf{N}$ & Mean $\pm S D$ & $\mathbf{N}$ & Mean $\pm S D$ & \\
\hline $0-3$ & 22 & $46.95 \pm 2.55$ & 75 & $40.80 \pm 4.72$ & 3.1238 \\
\hline $4-7$ & 12 & $50.17 \pm 1.47$ & 14 & $50.21 \pm 2.12$ & 0.9469 \\
\hline $8-11$ & 10 & $50.90 \pm 1.19$ & 3 & $51.67 \pm 0.58$ & 0.1687 \\
\hline $12-15$ & 4 & $51.50 \pm 1.73$ & 5 & $51.80 \pm 1.09$ & 0.7750 \\
\hline $16-18$ & 1 & $51.00 \pm 0.00$ & 0 & 0 & $<0.05^{*}$ \\
\hline
\end{tabular}




\begin{tabular}{|c|c|c|c|c|c|c|}
\hline \multirow[t]{3}{*}{ Parameters } & \multicolumn{6}{|c|}{ Mean $\pm S D$} \\
\hline & \multicolumn{3}{|c|}{ Children with SCD } & \multicolumn{3}{|c|}{ Children without SCD } \\
\hline & Males $(\mathrm{N}=54)$ & Females $(\mathrm{N}=49)$ & $\mathrm{p}$ value & Males $(\mathrm{N}=121)$ & Females $(\mathrm{N}=97)$ & $p$ value \\
\hline Cranial Index (C.I). & $79.13 \pm 3.29$ & $81.21 \pm 3.19$ & $0.0016^{*}$ & $79.16 \pm 3.19$ & $80.63 \pm 3.36$ & $0.0013^{*}$ \\
\hline Head circumference (HC). & $48.79 \pm 3.51$ & $49.00 \pm 2.72$ & 0.7418 & $46.49 \pm 5.71$ & $43.06 \pm 5.99$ & 2.6972 \\
\hline
\end{tabular}

between sexes for head circumference in both groups was not statistically significant ( $\mathrm{p}=0.74180$ and 2.6972$)$ as shown in Table 5.

\section{DISCUSSION}

The present study shows that cranial index values in children with SCD are similar to those of the normal growing children without SCD in every age group. Generally, the children with SCD had a higher cranial index (mean $\mathrm{CI}=80.12 \pm 3.39$ ) than those of without SCD (mean $\mathrm{CI}=79.82 \pm 3.35)$.

Results of skeletal changes in sickle cell disease patients are caused by marrow hyperplasia, infarcts and superadded infection. ${ }^{24}$ Chronic anemia is responsible for hyperplasia of bone marrow seen in bones and expansions in red bone marrow containing regions are caused by remodeling. ${ }^{25}$

In the skull of sickle cell disease patients are diploic thickening, granular texture, lamination of diploe and hair pattern. ${ }^{26}$ Cranial vault thickens with most contribution from diploic component and with resultant thinning of outer part. In a normal person with thick skull, all the component layers contribute to the overall thickness. ${ }^{26}$ Diploic thickening is significant in only the frontal and parietal regions with little involvement of the squamous part of temporal or occipital bone, giving the sickle cell disease patient a lower cranial index. ${ }^{5}$ Although, diploic thickening is non specific for the sickle cell disease skull as it is also a feature in other anemia related conditions such as severe iron deficiency, thalassemia. ${ }^{27}$ Growth deficit tends to be greater in width than in height or length and is more severe in patients with sickle cell anemia. ${ }^{28}$

The higher cranial index recorded in the sickle cell group corresponds to the brachycephalic head shape dominant in this group. Even though, the brachycephalization is more pronounced in the female sickle cell disease children where all the age groups are brachycephalic except for age group 8-11 years as against the sickle cell males where only age group 12-15 years is brachycephalic all the remaining age groups had the mesocephalic head shape as dominant. This finding does not tally with findings of previous researchers that reported the mesocephalic head shape as dominant among sickle cell patients. ${ }^{5}$

Head circumference values were found to be higher in sickle cell disease children (mean $\mathrm{OFC}=48.89 \pm 3.15$ ) than in normal growing non-sickle cell disease children (mean $\mathrm{OFC}=44.97 \pm 6.07$ ). This finding agrees with previous study that reported a higher head circumference in sickle cell anemia children as compared to that of normal growing children. ${ }^{8}$

\section{CONCLUSION}

The dominant head shape type as per the present study could be classified as mesocephalic in normal growing non-sickle cell disease children and brachycephalic in sickle cell disease children. Thus, it has been deduced that sickle cell disease could probably have an effect on head length, head width, cranial index and head circumference of affected children. Further studies should be conducted to corroborate these findings so as to make further inference due to clinical and anthropometric importance of such studies.

\section{REFERENCES}

1. Enlow DH and Hans MG. Essentials of Facial Growth. Philadelphia: W.B. Saunders Company, 1996.

2. Odunvbun ME, Okolo AA and Rahimy CM. Newborn screening for sickle cell disease in a Nigerian hospital. Public Health, 2008; 122:1111-1116.

3. Akinyanju OO. Profile of sickle cell disease in Nigeria. Ann N Y Acad Sci., 1989; 565:126-136.

4. Sergeant GR. Mortality from sickle cell disease in Africa. BMJ; 2005; 330: 432-433.

5. Fawehinmi HB and Ligha AE. Canthal and Cephalic Indexes of Children with Homozygous Sickle Cell Disease in Port-Harcourt. Nig J Med 2011; 20: 33-38.

6. Mukherjee MB and Gangakhedkar RR. Physical growth of children with sickle cell disease. Indian J Hum Genet 2004; 10: 70-72.

7. Lesi FEA. Anthropometric status of sickle cell anemia patients in Lagos, Nigeria. Nig Med J 1979; 74: 465-468.

8. Ejele OA, Asomugha AL and Fawehinmi HP. Some Morphometric changes associated with sickle cell anemia in the Niger Delta region of Nigeria. J Esp Clin Anat 2004; 3: 26-28.

9. Williams P, Dyson M, Dussak JE, Bannister LH, Berry, MM, Collins P and Ferguson MWJ. Gray's anatomy. Skeletal system. $38^{\text {th }}$ Edn. London, Elbs with Churchill Livingston, pp. 607-12; 1995. 
10. Golalipour MJ, Jahanshahi M and Haidari K. Morphological evaluation of head in Turkman males in Gorgan-North of Iran. Int J Morphol 2007; 25(1):99-102.

11. Grant TM and Peter AM. Size and shape measurement in contemporary cephalimeyrics. Eur J Orthod 2003; 25:231-242.

12. Larsen CS. Bioarcheology. Cambridge, Cambridge University Press; 1997.

13. Kouchi M. Brachycephalization in Japan has ceased. Am J Phys Anthropol 2002; 112:339-347.

14. Vojdani Z, Bahmanpour S, Momeni S, Vasaghi A, Yazdizadeh A, Karamifar A, et al.. Cephalometry in 14-18 years old girls and boys of Shiraz-Iran high school. Int J Morphol 2009; 27(1):101-104.

15. Golalipour MJ, Jahanshali $M$ and Haidari K. The variation of head and face shapes in females newborns in the southeast of the Caspian sea (mean Gorgam). Eur J Anat 2005; 9(2):95-98.

16. Rajlakshmi $\mathrm{CH}$, Shyamo-Singh $\mathrm{M}$, Bidhumukhi $\mathrm{TH}$ and handramani-Singh L. Cephalic index of fetuses of manipuri population - A baseline study. J Anat Soc India 2001; 50: 12-15.

17. Fawenhinmi $H B$ and Ligha $A E$. Subnasal to gnathion distance and nasal index of children with homozygous sickle cell disease in Port-Harcourt. Euro J Gen Med 2010; 7 (2): 197-202.

18. Hrdlika A. Practical Anthropometry. Steward T.D. (Editor). $4^{\text {th }}$ edition, Philadelphia. The Wistar Institute of Anatomy and Biology, 1956; 87-89.

19. Ruiz-Correa S, Raymond WS, Jacqueline RSD, Hen-Tzu JL, Matthew LS, et al.. New Scaphocephaly Severity Indices of Sagittal Craniosynostosis: A Comparative Study with Cranial
Index Quantifications. Cleft Palate-Craniofacial Journal 2005; $43 ; 2$.

20. Del Sol M. Cephalic index in a group of mapuche individuals in the IX Region of Chile. Int J Morphol 2005; 23(3):241-246.

21. National Health and Nutrition Examination Survey (NHANES) Anthropometry Procedure Manual, 2009. Available on: http://www.cdc.gov/nchs/data/nhanes/nhanes_09_10/ BodyMeasures_09.pdf. Accessed 19/12/2012.

22. Nellhaus G. Head circumference from birth to eighteen years: practical composite international and interracial graphs. Pediatrics 1968; 20-26.

23. A.D.A.M. Inc., 2011. Head circumference. http://www.scripps. org/articles/1907-growth-chart Accessed on 25/12/2012.

24. Lagundoye SB. Radiological features of sickle cell anemia and related haemoglobinopathies in Nigerians- a review article. Afr J Med Sci 1970; 1: 315-432.

25. Phatak SV, Kolwadlkar PK and Phatak MS. Pictorial essay: Radiographic skeletal changes in Sickle cell anemia. Ind J Radiol Imaging 2006; 16: 627-632.

26. Reynolds J. The skull and spine. Seminars in Roentgenology 1987; 22: 168-175.

27. Anat Burko H, Mellins $\mathrm{HZ}$ and Watson J. Skull changes of irondeficiencey anemia simulating congenital hemolytic anemia. Am J Roentgenol Radium THER Nucl Med 1961;86: 447-452.

28. Platt OS, Rosenstock W and Espeland MA. Influence of sickle haemoglobinopathies on growth and development. N Eng J Med $1984 ; 311-317$.

\footnotetext{
Authors Contribution:

MAM - Concept and Designing of the study, performed the measurements, analysed the data, drafted the manuscript, and reviewed the manuscript; MK - Contributed to the study design and data analysis; MD and HA - Contributed to the study design; ADZ - Reviewed the manuscript.
}

Source of Support: Nil, Conflict of Interest: None declared. 